\title{
Protective effect of sorbitol and monosodium glutamate during storage of freeze-dried lactic acid bacteria
}

\author{
Ana S. CARVALHO ${ }^{\mathrm{a}}$, Joana SILVA ${ }^{\mathrm{a}}$, Peter $\mathrm{HO}^{\mathrm{b}}$, Paula TEIXEIRA ${ }^{\mathrm{a} *}$, \\ F. Xavier MALCATA ${ }^{\mathrm{a}}$, Paul GIBBS ${ }^{\mathrm{a}}$

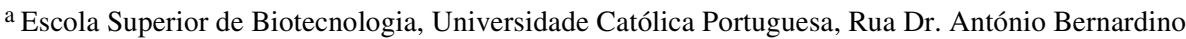 \\ de Almeida, 4200-072 Porto, Portugal \\ b Departamento de Ciências de Engenharia e Tecnologia, Escola Superior de Tecnologia e Gestão, \\ Instituto Politécnico de Viana do Castelo, Apartado 574, 4901-908 Viana do Castelo, Portugal
}

(Received 4 July 2002; accepted 6 January 2003)

\begin{abstract}
The effects of sorbitol and monosodium glutamate upon survival during storage of freeze-dried Lactobacillus bulgaricus, Lactobacillus plantarum, Lactobacillus rhamnosus, Enterococcus durans and Enterococcus faecalis were examined. There were no significant differences in survival during freeze-drying after addition of sorbitol or monosodium glutamate. However, these compounds were found to increase the stability of most strains during long-term storage. Various survival patterns were observed among the strains considered. However, for most of them, both compounds were proven effective in maintaining high degrees of viability over long periods of storage.
\end{abstract}

Starter culture / preservation / additive / processing / viability

Résumé - Effet protecteur du sorbitol et du glutamate monosodique pendant le stockage de bactéries lactiques lyophilisées. Les effets du sorbitol et du glutamate monosodique sur la survie des souches lyophilisées de Lactobacillus bulgaricus, Lactobacillus plantarum, Lactobacillus rhamnosus, Enterococcus durans et Enterococcus faecalis pendant le stockage ont été étudiés. On n'a pas trouvé de différences significatives pendant la lyophilisation, après l'addition de sorbitol ou de glutamate monosodique. Cependant, l'addition de ces composés a augmenté la stabilité de la plupart des souches pendant le stockage prolongé. Différents profils de survie ont été observés parmi les souches considérées ; toutefois, pour la plupart des souches les deux composés étaient efficaces dans le maintien de degrés élevés de viabilité pendant de longues périodes de stockage.

\section{Levain / conservation / additif / traitement / viabilité}

\section{INTRODUCTION}

Lactic acid bacteria (LAB) play crucial roles in the production of fermented food products, including dairy, vegetable, meat and wine [11]. Dried preparations have advantages of long-term preservation and convenience in handling, storage, marketing

* Correspondence and reprints

Tel.: +351 225580095; fax: +351 225090351; e-mail: paula@esb.ucp.pt 
and consumption. The industrial exploitation of LAB as starter and/or probiotic cultures relies heavily on the ability to concentrate and preserve them, so as to guarantee long-term delivery of viable and functional cultures [21]. Maximum survival of LAB starters during drying and subsequent storage is of vital importance technologically and economically [23].

Freeze-drying is often used in the preservation of LAB starter cultures, yet there are a few drawbacks associated therewith. Damage to biological systems resulting from freeze-drying can be attributed mainly to changes in the physical state of membrane lipids and changes in the structure of sensitive proteins [15]. Consequently, a number of studies have examined the potential role of additives in suspensions of microorganisms, such as sugars, polyols, amino acids, peptides and proteins, in their survival throughout freezing and drying [1, 7, 8, 14-17, 24]. However, even if survival is observed during freezing and/or drying, viability may be lost afterwards during the storage process, which thus hampers the final goal of those preservation technologies. Protective additives have an important role in the conservation of viability. A good protectant should provide cryoprotection of cells during freezedrying, be easily dried, and provide a good matrix to allow stability and ease of rehydration [4]. Sorbitol and monosodium glutamate (MSG) have been reported as efficient protectants $[1,11,17,22]$. An increase in residual activity and viability during drying following the addition of sorbitol to the drying medium has been previously reported for various organisms [1, 17]. Although the mechanism of protecting living cells by polyols is not fully understood, three hypotheses have been proposed so far that may be involved in cell protection [24]: (i) maintenance of turgor, resulting from the accumulation of mannitol at low water activity [13]; (ii) stabilisation of the structures of membrane lipids and proteins at low water activity $[15,25]$; and (iii) prevention of oxidative damage by scavenging of free reactive oxygen radicals [15]. The stabilisation of protein structures by reactions between the amino groups of the protectant and the carboxyl groups of the microorganism proteins, and the ability to retain greater amounts of residual moisture were put forward as tentative explanations of the protection by MSG during freezedrying [9].

The major objective of this study was thus to shed further light on the effects of sorbitol and monosodium glutamate upon survival during storage, following freezedrying of selected species of LAB.

\section{MATERIALS AND METHODS}

\subsection{Bacterial strains}

Lactobacillus delbrueckii ssp. bulgaricus, Lactobacillus plantarum and Lactobacillus rhamnosus were obtained from the culture collection held at Escola Superior de Biotecnologia; Enterococcus durans (two strains: ED1 and ED2) and Enterococcus faecalis (six strains: EF1, EF2, EF3, EF4, EF5 and EF6) were previously isolated from Portuguese hard cheeses, and duly characterised following DurluOzkaya et al. [6]. The original reference cultures were maintained in cryogenic storage on glass beads at $-80^{\circ} \mathrm{C}$. Working cultures were maintained as slopes on de Man-Rogosa-Sharp agar [5], (MRSa) (LAB M, Bury, UK) for Lactobacillus spp., and M17 agar (M17a) (Merck, Frankfurt, Germany) for Enterococcus spp. Slopes were stored at $4{ }^{\circ} \mathrm{C}$ and subcultured every month.

\subsection{Culture preparation}

Starting from the slopes, Lactobacillus spp. were inoculated in MRS broth and Enterococcus spp. in M17 broth, and incubated at $37^{\circ} \mathrm{C}$ for $24 \mathrm{~h}$. These cultures were then inoculated at $1 \%(\mathrm{v} / \mathrm{v})$ in a second broth, which was again incubated at $37^{\circ} \mathrm{C}$ for $24 \mathrm{~h}$. Cells were harvested in the 
stationary phase of growth by centrifugation at $7000 \mathrm{~g}$ for $10 \mathrm{~min}$, and washed twice with sterile Ringer's solution (LAB M). Washed cells were then resuspended in sterile skim milk containing $11 \%(\mathrm{w} / \mathrm{v})$ solids (LAB M), and skim milk containing selected concentrations of the compounds to be tested: $12.5 \mathrm{~g} \cdot \mathrm{L}^{-1}$ sorbitol (Sigma, St. Louis, MO, USA) and $12.5 \mathrm{~g} \cdot \mathrm{L}^{-1}$ monosodium glutamate (MSG) (Sigma). Cellular suspensions were maintained for $1 \mathrm{~h}$ at room temperature prior to freezing $\left(-80^{\circ} \mathrm{C}\right.$ for $24 \mathrm{~h}$ ), in order to allow for equilibration between the cells and the compound added. The experiments were repeated twice.

\subsection{Freeze-drying and storage}

Samples of $20 \mathrm{~mL}$ were desiccated under vacuum (50 mtorr for $48 \mathrm{~h}$ ) in a freeze-drier (Martin Christ, Osterad am Harz, Germany), at room temperature $\left(20^{\circ} \mathrm{C}\right)$; the condenser was cooled at $-55^{\circ} \mathrm{C}$. Dried cells were stored in closed containers at $20^{\circ} \mathrm{C}$ in air, and maintained in the darkness.

\subsection{Enumeration of survivors}

Freeze-dried samples were periodically picked up at random during storage, and were rehydrated to the original volume using sterile deionised water. Suitable dilutions in Ringer's solution were then plated on MRSa for Lactobacillus spp. and M17a in the case of Enterococcus spp., using the drop count technique [18]: three drops ( $20 \mu \mathrm{L}$ each) of the suitable dilution were placed on each of three separate plates. Plates were examined after incubation at $37^{\circ} \mathrm{C}$ for $48 \mathrm{~h}$.

\subsection{Statistical analysis}

The means of three replicated viable counts for each of two replicated experiments, after freeze-drying and at regular time intervals during storage, were subject to analysis of variance (ANOVA) using the statistical program R [12]. Statistical differences were considered at a 0.05 level of significance. Multiple comparison of treatment means was done using a $95 \%$ confidence interval based on Tukey's honestly significant difference (HSD); subsequently, error bars using these HSD values were plotted along with mean values using the Trellis display [3].

\section{RESULTS}

The addition of sorbitol or MSG did not affect the viability of the bacterial suspensions before freezing for any strain (data not shown). Comparative data pertaining to the influence of sorbitol and MSG, added to the medium, on the viability of several species of $\mathrm{LAB}$ during freeze-drying and subsequent storage are displayed in Table I and Figure 1, respectively. A full threefactor analysis of variance, considering replication of freeze-drying (experimental replication), added compound and storage time, was carried out for each microorganism. Table II shows the typical results of an ANOVA table, specifically for $E$. faecalis 1 . For all LAB tested, the experimental replication and its two-way interactions with the other two factors were not significant. However, the main effects of added compound and storage time, along with their two-way interactions were statistically significant $(P<0.05)$. In order to compare the differences between mean values of survival at any specific point during storage, multiple comparison of means was done based on Tukey's HSD. Due to the statistical significance of the 2-way interactions between added compound and storage time, multiple comparisons should be conducted using their individual treatment means and not their factor level means [19].

All five species experienced decreases in viability during dehydration, but Enterococcus spp. were observed to be more resistant than Lactobacillus spp. during storage. Comparing the lower and upper 
Table I. Survival (in $\log \left(\mathrm{CFU} \cdot \mathrm{mL}^{-1}\right)$ ) of lactic acid bacteria during freeze-drying in the presence of skim milk (control), skim milk with $12.5 \mathrm{~g} \cdot \mathrm{L}^{-1}$ sorbitol and skim milk with $12.5 \mathrm{~g} \cdot \mathrm{L}^{-1}$ MSG. Each value represents the mean of 3 replicates from 2 freeze-drying experiments (6 values in all); error bars are Tukey's HSD based on 95\% confidence intervals of treatment means.

\begin{tabular}{|c|c|c|c|c|c|c|c|c|c|c|c|c|c|}
\hline \multirow[b]{3}{*}{ Species } & \multicolumn{7}{|c|}{ Before freeze-drying } & \multicolumn{6}{|c|}{ After freeze-drying } \\
\hline & \multicolumn{4}{|c|}{ Control } & \multicolumn{3}{|c|}{ Control } & \multicolumn{3}{|c|}{ Sorbitol } & \multicolumn{3}{|c|}{ MSG } \\
\hline & Strain & Lower & Mean & Upper & Lower & Mean & Upper & Lower & Mean & Upper & Lower & Mean & Upper \\
\hline L. plantarum & & 8.75 & 9.05 & 9.35 & 8.13 & 8.43 & 8.73 & 7.95 & 8.25 & 8.55 & 8.32 & 8.62 & 8.92 \\
\hline L. rhamnosus & & 8.60 & 8.89 & 9.18 & 7.97 & 8.26 & 8.55 & 8.10 & 8.39 & 8.68 & 8.02 & 8.31 & 8.60 \\
\hline L. bulgaricus & & 8.10 & 8.33 & 8.56 & 6.81 & 7.04 & 7.27 & 6.95 & 7.18 & 7.41 & 6.78 & 7.08 & 7.31 \\
\hline \multirow{3}{*}{ E. durans } & ED 1 & 7.91 & 8.31 & 8.71 & 7.64 & 8.04 & 8.44 & 7.71 & 8.11 & 8.51 & 7.74 & 8.14 & 8.54 \\
\hline & ED 2 & 8.19 & 8.59 & 8.99 & 7.22 & 7.62 & 8.02 & 7.56 & 7.96 & 8.36 & 7.51 & 7.91 & 8.31 \\
\hline & EF 1 & 8.09 & 8.43 & 8.77 & 7.65 & 7.99 & 8.33 & 7.77 & 8.11 & 8.45 & 7.75 & 8.09 & 8.43 \\
\hline \multirow{5}{*}{ E. faecalis } & $\mathrm{EF} 2$ & 8.67 & 9.01 & 9.35 & 7.68 & 8.02 & 8.36 & 7.80 & 8.14 & 8.48 & 7.77 & 8.11 & 8.45 \\
\hline & EF 3 & 8.18 & 8.54 & 8.90 & 7.73 & 8.09 & 8.45 & 7.90 & 8.26 & 8.62 & 7.82 & 8.18 & 8.54 \\
\hline & $\mathrm{EF} 4$ & 8.28 & 8.59 & 8.90 & 7.87 & 8.18 & 8.49 & 7.82 & 8.13 & 8.44 & 8.10 & 8.41 & 8.72 \\
\hline & EF 5 & 8.00 & 8.38 & 8.76 & 7.71 & 8.09 & 8.47 & 7.62 & 8.00 & 8.38 & 7.70 & 8.08 & 8.46 \\
\hline & EF 6 & 8.32 & 8.65 & 8.98 & 7.61 & 7.94 & 8.27 & 7.66 & 7.99 & 8.32 & 7.81 & 8.14 & 8.47 \\
\hline
\end{tabular}

Table II. ANOVA table of the effects of sorbitol and MSG on survival during freeze-drying, and subsequent storage of E. faecalis 1 .

\begin{tabular}{lcccc}
\hline Source of variation & $\begin{array}{c}\text { Sum of } \\
\text { squares }\end{array}$ & $\begin{array}{c}\text { Degrees of } \\
\text { freedom }\end{array}$ & Mean squares & $\boldsymbol{F}$-ratio \\
\hline Experimental replication (ER) & 0.025 & 2 & 0.012 & 1.044 \\
Storage time (ST) & 49.302 & 9 & 5.478 & $459.111^{*}$ \\
Added compound (AC) & 0.224 & 2 & 0.112 & $9.394^{*}$ \\
$\mathrm{ER} \times \mathrm{ST}$ & 0.082 & 18 & 0.005 & 0.383 \\
$\mathrm{ER} \times \mathrm{AC}$ & 0.016 & 4 & 0.004 & 0.336 \\
$\mathrm{ST} \times \mathrm{AC}$ & 4.791 & 18 & 0.266 & $22.308^{*}$ \\
$\mathrm{ER} \times \mathrm{ST} \times \mathrm{AC}$ & 0.125 & 36 & 0.003 & 0.209 \\
Residuals & 1.074 & 90 & 0.012 & \\
\hline
\end{tabular}

$* P<0.0001$.

limits of mean error for survival during freeze-drying after addition of sorbitol and MSG, we can see that there are no significant differences in their survival relative to the control (Tab. I). However, Figure 1 indicates that addition of sorbitol and MSG to the drying medium significantly increased survival of most strains during storage. Lactobacillus bulgaricus and L. rhamnosus strains exhibited significantly higher survival degrees during storage when the pro- tective agent was sorbitol; conversely, there were no significant differences between addition of sorbitol or MSG in the case of L. plantarum.

At the end of the storage period tested (8 months), the degree of survival of the strains E. faecalis $\mathrm{EF} 1$ and E. durans ED2 was not dependent on the protective agent used. However, between 3 and 6 months of storage, sorbitol was effective in protecting ED2 cells from loss of viability. Enterococcus 

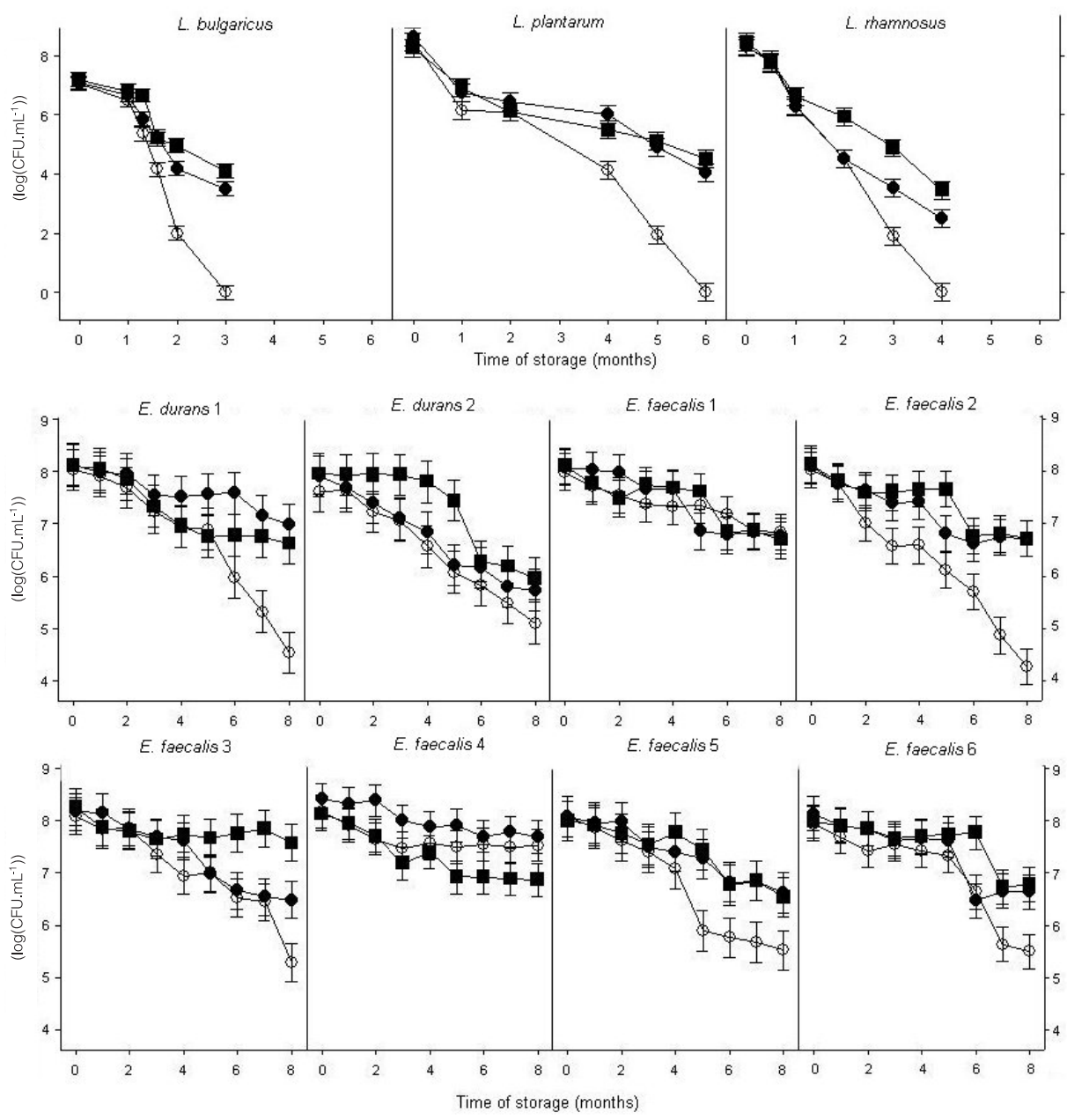

Figure 1. Survival (in $\log \left(\mathrm{CFU} \cdot \mathrm{mL}^{-1}\right)$ ) of lactic acid bacteria during storage, following freeze-

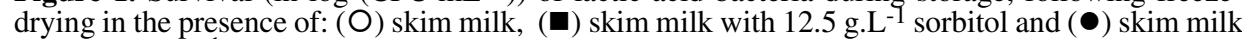
with $12.5 \mathrm{~g} \cdot \mathrm{L}^{-1} \mathrm{MSG}$. Each value represents the mean of 3 replicates from 2 freeze-drying experiments (6 values in all); error bars are Tukey's HSD based on $95 \%$ confidence intervals of treatment means ( 0.30 for L. plantarum; 0.29 for L. rhamnosus; 0.23 for L. bulgaricus; 0.40 for E. durans; 0.31-0.38 for E. faecalis).

durans strain ED1 and E. faecalis strains EF2, EF5 and EF6 exhibited a significantly higher survival degree during storage when sorbitol or MSG had been added to the skim milk medium; for those four strains, there were no significant differences between these two protectants. Sorb- itol was proven to be the best protective agent for E. faecalis strain EF3 during storage, whereas strain EF4 survived significantly better in the absence of sorbitol.

It can also be concluded from Figure 1 that survival throughout storage was strongly dependent on the bacterium being 
tested. Therefore, the degree of protection during storage afforded by a given additive is species- and strain-dependent.

\section{DISCUSSION}

Freeze-drying has long been considered as a suitable dehydration process for bacteria, aimed at achieving a solid and stable final formulation. The choice of an appropriate drying medium is thus very important in the case of LAB, in order to increase their survival rates during dehydration itself and subsequent storage. Skim milk powder has been selected as drying medium because it creates a porous structure in the freeze-dried product that makes rehydration easier; it is also believed that proteins in milk provide a protective coating for the cells [1]. Supplementing skim milk with protective agents may enhance the intrinsic effect of protection during storage to different degrees, depending on the compound added. The ability of a compound to preserve the viability of cells during periods of desiccation has been associated either with the presence of an amino group, a secondary alcohol group, or both [8].

Our experimental results demonstrated that sorbitol has a strong protective effect upon the survival of $L$. bulgaricus, L. plantarum, L. rhamnosus, E. faecalis and E. durans during storage, even though no significant differences were observed in terms of viability of cells during freezedrying in the presence or absence of sorbitol. Similar results were obtained by Fonseca et al. [7], who have shown that there is no effect of glycerol during freezing of Streptococcus thermophilus, although a positive effect was observed during frozen storage. Substantial increases in residual activity and viability after drying, following addition of sorbitol to the drying medium, have been reported $[1,17]$ for various organisms, although there is not a general consensus [8]. Damage to biological systems derived from freeze-drying has been attributed to two primary causes: (i) changes in the physical state of the membrane lipids, and (ii) changes in the structure of sensitive proteins in the cell [15]. The mechanisms underlying sorbitol protection of dried cells would thus be: (i) prevention of damage to the membrane via interaction therewith [16], and prevention of lipid oxidation owing to its anti-oxidant properties [17]; (ii) stabilisation of protein structure, and hence preservation of functionality associated with the formation of sorbitol-protein complexes [25]; and (iii) maintenance of turgor, owing to the accumulation of said additive [24].

The ability of MSG to protect distinct microorganisms during cryopreservation and freeze-drying has previously been described [9, 11, 22]. Abadias et al. [1] claimed that MSG, when used alone, was very effective in preserving Candida sake cells during lyophilisation; however, combination of MSG with skim milk destroyed that favourable effect. Our results show that the majority of the LAB tested experience, after freeze-drying in the presence of MSG, increased survival during storage. The stabilisation of their protein structure via reactions between the amino group of the protectant and the carboxyl groups of the microorganism proteins, and the ability to retain greater amounts of residual moisture have been pointed out [8] as explanations that account for protection by MSG during freeze-drying.

The data presented in this paper demonstrate that different species and strains may exhibit distinct behaviours during storage in the dried state. Possible reasons for such a realisation are somewhat puzzling; it was suggested [20] that gene transfer between strains may lead to differences in phenotype between various Lactococcus lactis strains. Previous work claimed an effect of bacterial cell size on survival during freezing and freeze-drying [2, 7]; according to Fonseca et al. [7], the higher the surface area of the cell, the higher the membrane damage due to extracellular ice crystal formation during freezing. This could provide 
a possible explanation for the results presented, since it was observed that the survival of the various species was related to their size: enterococci (small spherical cells) were more resistant during storage in the dried state than lactobacilli (larger rods). Furthermore, enterococci have been recognised for their notable resistance to adverse environmental conditions [10].

The mechanisms underlying damage and protection by freezing, drying and storage are indeed complex, and not fully understood to date. Although this work does not allow final conclusions on the mode of action of sorbitol and MSG to be drawn, evidence is presented that suitable selection of the composition of the drying medium is essential to afford protection during storage afterwards. It should also be emphasised that the influence of each protective agent on the survival of each LAB strain in the dried state should be determined on a case-to-case basis; however, sorbitol and MSG may in general be considered effective in protecting freezedried LAB during storage.

\section{ACKNOWLEDGEMENTS}

This work received partial financial support via project PRAXIS/P/BIO/12147/1998 (FCT, Portugal), co-ordinated by P. Teixeira and P. Gibbs. Financial support for authors A.S. Carvalho and J. Silva was provided by Ph.D. fellowships PRAXIS XXI/BD/18152/98 and PRAXIS XXI/BD/197131/99, respectively (FCT, Portugal).

\section{REFERENCES}

[1] Abadias M., Benabarre A., Teixidó N., Usall J., Viñas I., Effect of freeze-drying and protectants on viability of the biocontrol yeast Candida sake, Int. J. Food Microbiol. 65 (2001) 173-182.

[2] Bazoglu T.F., Özilgen M., Bakir U., Survival kinetics of lactic acid starter cultures during and after freeze-drying, Enzyme Microb. Technol. 9 (1987) 531-537.

[3] Becker R.A., Cleveland W.S., Shyu M.-J., The visual design and control Trellis display, J. Comp. Graphic Stat. 5 (1995) 123-155.

[4] Costa E., Usall J., Teixidó N., Garcia N., Viñas I., Effect of protective agents, rehydration media and initial cell concentration on viability of Pantoea agglomerans strain CPA-2 subjected to freeze-drying, J. Appl. Microbiol. 89 (2000) 793-800.

[5] de Man J.C., Rogosa M., Sharpe M.E., A medium for the cultivation of lactobacilli, J. Appl. Bacteriol. 23 (1960) 130-135.

[6] Durlu-Ozkaya F., Xanthopoulos V., Tunaii N., Litopoulou-Tzanetaki E., Technologically important properties of lactic acid bacteria isolates from Beyaz cheese made from raw ewe's milk, J. Appl. Microbiol. 91 (2001) 861-870.

[7] Fonseca F., Béal C., Corrieu G., Method for quantifying the loss of acidification activity of lactic acid starters during freezing and frozen storage, J. Dairy Res. 67 (2000) 83-90.

[8] Font de Valdéz G., de Giori G., de Ruiz Holgado A.P., Oliver G., Protective effect of adonitol on lactic acid bacteria subjected to freeze-drying, Appl. Environ. Microbiol. 45 (1983) 302-304.

[9] Font de Valdéz G., de Giori G., de Ruiz Holgado A.P., Oliver G., Effect of drying medium on residual moisture content and viability of freeze-dried lactic acid bacteria, Appl. Environ. Microbiol. 49 (1985) 413-415.

[10] Giraffa G., Enterococci from foods, FEMS Microbiol. Rev. 744 (2002) 1-9.

[11] Hubalék Z., Cryopreservation of microorganisms, Academia, Prague, Czech Republic, 1996.

[12] Ihaka R., Gentleman R., R: A language for data analysis and graphics, J. Comp. Graphic Stat. 5 (1996) 299-314.

[13] Kets E.P.W., Galinski E.A., De Wit M., De Bont J.A.M., Heipieper H.J., Mannitol, a novel bacterial compatible solute in Pseudomonas putida S12, J. Bacteriol. 178 (1996) 6665-6670.

[14] Konings W.N., Kok J., Kuipers O.P, Poolman B., Lactic acid bacteria: the bugs of the new millennium, Curr. Opin. Microbiol. 3 (2000) 276-282.

[15] Leslie S.B., Israeli E., Lighthart B., Crowe J.H., Crowe L.M., Trehalose and sucrose protect both membranes and proteins in intact bacteria during drying, Appl. Environ. Microbiol. 61 (1995) 3592-3597.

[16] Linders L.J.M., de Jong G.I.W., Meerdink G., van't Riet K., Carbohydrates and the 
dehydration inactivation of Lactobacillus plantarum: the role of moisture distribution and water activity, J. Food. Eng. 31 (1997) 237-250.

[17] Linders L.J.M., Wolkers W.F., Hoekstra F.A., van't Riet K., Effect of added carbohydrates on membrane phase behaviour and survival of dried Lactobacillus plantarum, Cryobiology 35 (1997) 31-40.

[18] Miles A.A., Misra S.S., The estimation of the bactericidal power of blood, J. Hyg. 38 (1938) 732-749.

[19] Neter J., Kutner M.H., Nachtsheim C.J., Wasserman W., Applied Linear Statistical Models, Irwin, Chicago, USA, 1996.

[20] O'Callaghan J., Condon S., Growth of Lactococcus lactis strains at low water activity: correlation with the ability to accumulate glycine and betaine, Int. J. Food Microbiol. 55 (2000) 127-131.
[21] Palmfedt J., Hahn-Hägerdal B., Influence of culture $\mathrm{pH}$ on survival of Lactobacillus reuteri subjected to freeze-drying, Int. J. Food Microbiol. 55 (2000) 235-238.

[22] Porubcan R.S., Sellars R.L., Stabilized dry cultures of lactic acid-producing bacteria, US Patent 3897307 (1975).

[23] Selmer-Olsen E., Birkeland S.-E., Sørhaug T., Effect of protective solutes on leakage from and survival of immobilized Lactobacillus subjected to drying, storage and rehydration, J. Appl. Microbiol. 87 (1999) 429-437.

[24] Wisselink H.W., Weusthuis R.A., Eggink G., Hugenholtz J., Grobben G.J., Mannitol production by lactic acid bacteria: a review, Int. Dairy J. 12 (2002) 151-161.

[25] Yoo B., Lee C.M., Thermoprotective effect of sorbitol on proteins during dehydration, J. Agric. Food Chem. 41 (1993) 190-192. 